\title{
Treatment and use of wastewater in Mexicali, Baja California, Mexico
}

\author{
S. Romero ${ }^{1}$, A. Villagomez ${ }^{1}$, D. Trasviña ${ }^{1}$, J. García $^{2}$, R. Gallegos ${ }^{3}$, \\ J. Reyes ${ }^{1}$, J. Ramírez ${ }^{1}$ \& F. Solís ${ }^{4}$ \\ ${ }^{1}$ Instituto de Ingeniería, Universidad Autónoma \\ de Baja California, Mexico \\ ${ }^{2}$ Centro de Investigación en Alimentación y Desarrollo AC (CIAD) \\ Guaymas, Mexico \\ ${ }^{3}$ Facultad de Arquitectura, Universidad Autónoma \\ de Baja California, Mexico \\ ${ }^{4}$ Facultad de Ingeniería, Universidad Autónoma \\ de Baja California, Mexico
}

\begin{abstract}
This study had, as its objective, the assessment of the current state of the treatment and use of domestic wastewater in the municipality of Mexicali, in the state of Baja California in Mexico. A diagnosis of the treatment process was undertaken and the quality of the effluent produced in 2010 by each wastewater treatment plant (WTP) was assessed. A comparison was then made with the limits established in the Mexican regulations for use of treated wastewater. Finally, an action plan was developed to improve the use of this resource. The results of the study show that none of the WTPs complied with the limits of the official Standard NOM-003-SEMARNAT-1997 for suspended solids (TSS) and biochemical oxygen demand $\left(\mathrm{BDO}_{5}\right)$. The WTP of greatest interest is Arenitas, because its effluent is being used for agricultural irrigation. Concentrations of fecal coliforms in the effluent of this WTP ranged between 340 and 86,740 MPN/100 ml over a six month period, while the limit is $240 \mathrm{MPN} / 100 \mathrm{ml}$. The concentration of total suspended solids (TSS) was detected at between 32 and $116 \mathrm{mg} / \mathrm{l}$, while the limit is $30 \mathrm{mg} / \mathrm{l} . \mathrm{BDO}_{5}$ was detected at between 28 and $55 \mathrm{mg} / \mathrm{l}$, while the limit is $30 \mathrm{mg} / \mathrm{l}$. Only in the month of April did these measurements fall below the limit of $15 \mathrm{mg} / \mathrm{l}$ for grease and oil.

Keywords: water pollution, use of treated wastewater, agricultural irrigation.
\end{abstract}




\section{Introduction}

Water is a vital resource for human activities, for economic development and public health. However, rapid population growth (especially in developing countries), the pollution of surface water bodies and groundwater, the uneven distribution of water resources and severe dry periods have forced the search for new water supply sources. Treated wastewater is, therefore, now regarded as an additional source to satisfy demand for this vital resource (Silva et al. [1]). Currently, the population in Mexico exceeds 112 million inhabitants, with an annual population growth rate of $1.8 \%$ (INEGI [2]). While Figure 1 shows a decreasing trend in the availability of water per capita per year from 1950 to 2010, an availability projection for the year 2030 was estimated at 3,783 cubic meters per capita per year.

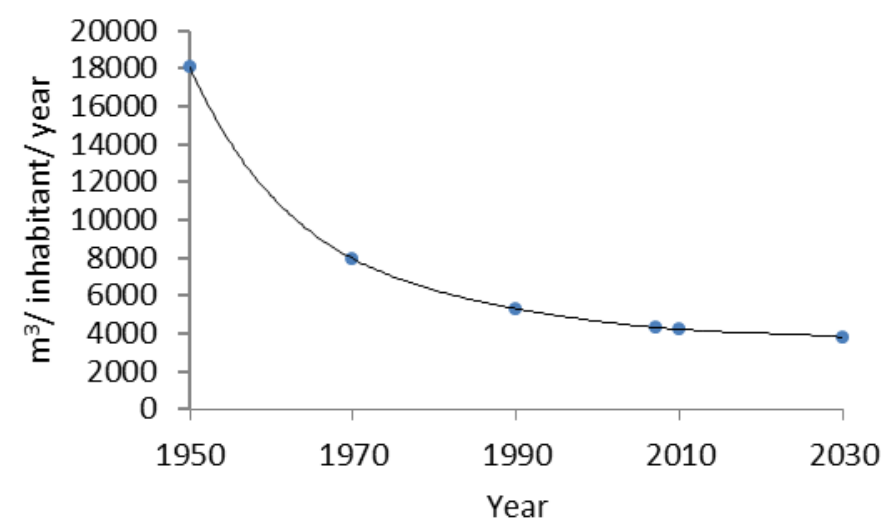

Figure 1: Natural average availability of water in Mexico.

Mexico has an estimated water resources amount to approximately 410,000 million cubic meters of water. Most of the water consumed (79.5\%) is used in agriculture irrigation activities. The remainder used in the industrial and domestic sectors (CONAGUA [3]). It is estimated that by the year 2025, the global availability of freshwater per capita will descend to $5,100 \mathrm{~m}^{3}$ per person per year (CONAGUA [4]). This trend indicates that Mexico will soon be facing serious problems with water availability.

\subsection{Availability of water resources in Mexicali and the Mexicali Valley}

The city of Mexicali in Baja California is located in the northwest of Mexico. Its climate is classified as arid and semi-arid, with $203.7 \mathrm{~mm}$ rainfall recorded in the state per year in the period between the years 1941-2009 (CONAGUA [3]). The low levels of rainfall in the state are especially serious for the recharge of aquifers, whose flow depends on rainfall infiltration (Colima [5]). Due to 
significant industrial and agricultural development in Mexicali, water consumption is high and supplies are limited, with most of this resource destined for agricultural activity. The city of Mexicali is supplied by 1,850 million cubic meters of water from the Colorado River, which flows from its source as snowmelt at an altitude of 14,275 meters in the Rocky Mountains in the North of the state of Colorado in the United States of America. The river runs along approximately 2,735 kilometers, and supplies water to about 30 million people, irrigating more than 1.5 million hectares of agricultural land in the states of Wyoming, Colorado, Utah, New Mexico, Arizona, Nevada, California, finally crossing the Mexican border into the state of Baja California, and emptying into the Sea of Cortez (as shown in Figure 2). The second source of water supply for the agricultural region of Mexicali comes from the extraction of an aquifer with a volume of 700,000 cubic meters, which is pumped from 725 deep wells located in the Mexicali Valley (Acosta [6]). The Colorado River enables the irrigation of approximately 200,000 hectares in the Valley's agricultural zone. It is expected that water availability will be reduced in the coming years (INEGI [2]).

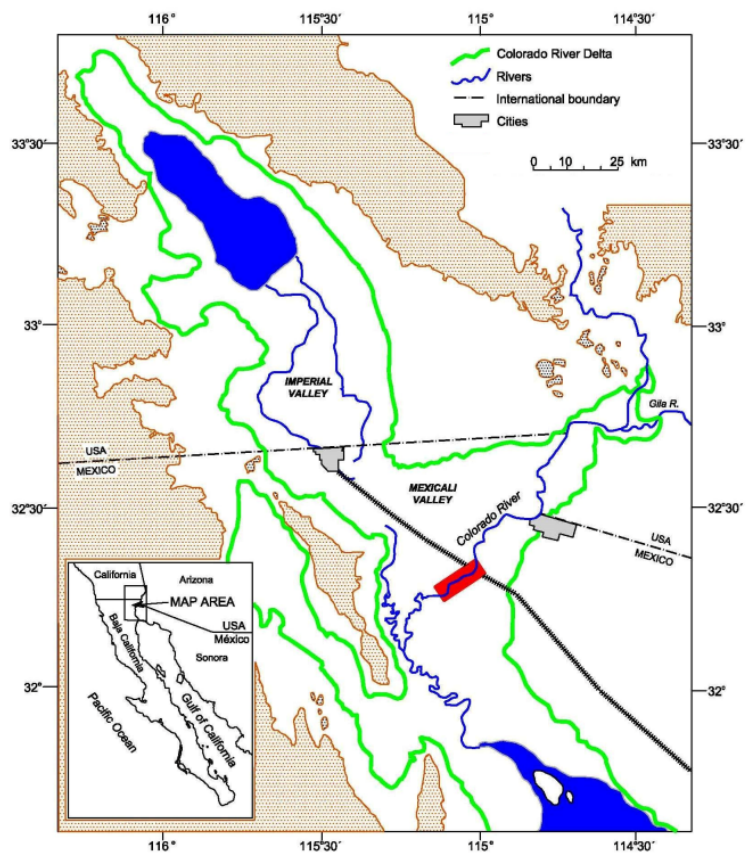

Figure 2: $\quad$ Pathway of the Colorado River in the study area.

\subsection{Experiences in the use of treated wastewater}

Experiments with use of treated wastewater have been conducted in different parts of the world, with Israel at the forefront of this research. It is estimated that a tenth or more of the entire world population currently consumes foods that are 
produced with wastewater, although they have not always been produced safely (Strauss [7]). In 2008, the Orange County, California in the United States launched a system for the recycling of wastewater for human consumption, which is capable of producing some 265 million liters a day. According to its managers, the treated water surpasses the State and Federal minimum limits (Fernández [8]), although among the general population there is resistance to use recycled water for human consumption. In Ibague, Colombia, there is a proposal for the use of the wastewater taken from the facultative lagoons used in the irrigation systems for rice, sorghum, pastures, soybeans, and cotton. The proposed volume to be treated was $1438.66 \mathrm{l} / \mathrm{s}$, with health risks defined as the main impact of the indirect and unsure use of diluted wastewater (Cepis [9]).

\section{Regulations for the use of treated wastewater in Mexico}

The term water care relates to all actions that help to protect and reuse water responsibly, with the use of treated wastewater currently being one of the main strategies for this purpose (Rivera et al. [10]). For this reason, it is important to comply with the norms and standards established for the use of treated water. Regulations in Mexico permit the unrestricted use of wastewater for the planting, growing and harvesting of agricultural products limited to forages and grains, while its use is restricted solely to the irrigation of vegetables and legumes. The official Mexican standard NOM-003-SEMARNAT-1997 (SEMARNAT [11]) sets permissible maximum contaminant levels for the treated wastewater used in public services, in order to protect both the environment and public health. This standard establishes that the concentrations of basic pollutants, heavy metals and cyanides shall not exceed the value indicated as the maximum allowable limit. The permissible range of $\mathrm{pH}$ is from 5 to 10 . The maximum permissible limits of the main pollutants in treated wastewater are illustrated in Table 1. Floating matter must be absent, according to the testing method established in the Mexican norm NMX-AA-006.

Table 1: Maximum permissible limits of main pollutants.

\begin{tabular}{|l|c|c|c|c|c|}
\hline \multirow{2}{*}{ Purpose } & \multicolumn{5}{|c|}{ Monthly average } \\
\cline { 2 - 6 } & $\begin{array}{c}\text { Fecal coliforms } \\
\text { MPN/100 ml }\end{array}$ & $\begin{array}{c}\text { Helminth } \\
\text { eggs } \\
\text { (h/l) }\end{array}$ & $\begin{array}{c}\text { Grease } \\
\text { and oil } \\
\mathrm{mg} / \mathrm{l}\end{array}$ & $\begin{array}{c}\mathrm{BDO}_{5} \\
\mathrm{mg} / \mathrm{l}\end{array}$ & $\begin{array}{c}\mathrm{TSS} \\
\mathrm{mg} / \mathrm{l}\end{array}$ \\
\hline $\begin{array}{l}\text { Public services with direct } \\
\text { contact with treated } \\
\text { wastewater }\end{array}$ & 240 & $\leq 1$ & 15 & 20 & 20 \\
\hline $\begin{array}{l}\text { Public services with } \\
\text { indirect or occasional } \\
\text { contact with treated } \\
\text { wastewater }\end{array}$ & 1,000 & $\leq 5$ & 15 & 30 & 30 \\
\hline
\end{tabular}




\section{Method}

A diagnosis of the treatment process used on the domestic wastewater produced by the city of Mexicali and the Mexicali Valley was undertaken in this study. An inventory of each WTP was developed, which included the volume of treated wastewater and the current or potential applications if treated wastewater is not used or partially used. Laboratory analysis, were performed for fecal coliforms, biochemical oxygen demand $\left(\mathrm{BDO}_{5}\right)$, suspended solids, grease and oil (helminth eggs were not analyzed). These analysis were conducted by the Comisión Estatal de Servicios Públicos de Mexicali (CESPM), which is responsible for water management in the municipality. The results of laboratory analysis conducted on the effluent from each plant were compared to the maximum permissible limits established by the Mexican Standard NOM-003-SEMARNAT-1997. The critical aspects in the treatment of wastewater and the use of effluents were identified, and, on this basis, a strategic plan to improve the use of treated wastewater was developed.

\section{Results}

\subsection{Use of treated wastewater in Mexicali}

The results show that in 2010, a total of 52,944,529 cubic meters of wastewater was treated. Table 2 shows the distribution of the uses of this water.

Table 2: $\quad$ Distribution of uses of treated wastewater in Mexicali.

\begin{tabular}{|c|c|c|c|}
\hline Green areas & Industry & Agriculture & Ecological uses \\
\hline $1.1 \%$ & $19.8 \%$ & $14.0 \%$ & $37.3 \%$ \\
\hline
\end{tabular}

A purple pipeline, covering a total area of approximately 22.3 kilometers, currently delivers treated wastewater to the urban area.

\subsection{Inventory of wastewater treatment plants currently in operation}

Mexicali has seven domestic wastewater treatment plants. The WTPs Zaragoza and Arenitas, are important because they treat the largest volume of wastewater. This is due their close proximity to the urban area and, primarily, because their effluent is being used in the industrial sector, for ecological applications, for the irrigation of green areas, to supply the purple pipeline for fire hydrants, and to recharge rivers for both agricultural and recreational activity. Table 3 presents the inventory of the WTPs, detailing the volume of water treated, the various uses given to each fraction of that volume, and the potential uses to which it can be applied. 
Table 3: Inventory of wastewater treatment plants.

\begin{tabular}{|c|c|c|c|}
\hline WTP & $\begin{array}{l}\text { Volume } \\
\text { Treated in } \\
2010\left(\mathrm{~m}^{3}\right) \\
\end{array}$ & Current use & Potential use \\
\hline Zaragoza & 25448039 & $\begin{array}{l}\text { Cooling water for electric } \\
\text { generation plants. Irrigation in } \\
\text { Module 20. Recharge of Salton } \\
\text { Sea }\end{array}$ & $\begin{array}{l}\text { Extension of the } \\
\text { irrigation area of } \\
\text { Irrigation Module } 20\end{array}$ \\
\hline $\begin{array}{l}\text { Las } \\
\text { Arenitas }\end{array}$ & 23459783 & $\begin{array}{l}\text { Agricultural irrigation and } \\
\text { ecological use in the Hardy } \\
\text { River }\end{array}$ & Aquifer recharge. \\
\hline $\begin{array}{l}\text { Estación } \\
\text { Coahuila }\end{array}$ & 280240 & Not currently used & $\begin{array}{l}\text { Agricultural irrigation. } \\
\text { Irrigation of urban } \\
\text { green areas. }\end{array}$ \\
\hline Algodones & 227501 & Not currently used & $\begin{array}{l}\text { Agricultural irrigation. } \\
\text { Irrigation of urban } \\
\text { green areas. } \\
\text { Aquifer recharge. }\end{array}$ \\
\hline $\begin{array}{l}\text { Ciudad } \\
\text { Morelos }\end{array}$ & 475424 & Not currently used & $\begin{array}{l}\text { Agricultural irrigation. } \\
\text { Irrigation of urban } \\
\text { green areas. }\end{array}$ \\
\hline $\begin{array}{l}\text { Ciudad } \\
\text { Victoria }\end{array}$ & 826410 & Not currently used & $\begin{array}{l}\text { Agricultural irrigation. } \\
\text { Irrigation of urban } \\
\text { green areas. }\end{array}$ \\
\hline San Felipe & 2227132 & $\begin{array}{l}\text { Irrigation of agricultural and } \\
\text { green areas. Golf course } \\
\text { irrigation. Aquifer recharge. }\end{array}$ & $\begin{array}{l}\text { Irrigation of } \\
\text { agricultural and green } \\
\text { areas. } \\
\text { Golf course irrigation. } \\
\text { Aquifer recharge. }\end{array}$ \\
\hline
\end{tabular}

\subsection{Laboratory results and comparison with official standards}

The results of the physical, chemical and bacteriological analyses of each WTP effluent were compared with the maximum permissible limits established by NOM-003-SEMARNAT-1997. The review of laboratory analysis results revealed that the effluent from the seven plants does not comply with the permissible limits for direct contact. None of the WTPs complies with the limit of the concentration of suspended solids and biochemical oxygen demand. In addition to the above parameters, in some months the WTPs shown in Table 4 do not meet the limit for fecal coliforms.

The WTP of greatest interest in Mexicali is Arenitas, because it is one of the plants which treats the highest volume of water, with its effluent being used to irrigate agricultural crops and for ecological use in the Hardy River. This river is used for intensive recreational activity involving direct contact with water.

Figure 3 shows that, throughout the year, the $\mathrm{BDO}_{5}$ limit for direct contact (DCL) was exceeded, while the limit for indirect contact (ICL) was only complied with for two months in the year. It was also noted that the concentration of suspended solids exceeded both the 20 and $30 \mathrm{ml} / 1$ limits 
Table 4: Fecal coliforms in WTPs not meeting the standard in 2010.

\begin{tabular}{|c|c|c|c|c|c|}
\hline & \multicolumn{3}{|c|}{ PLANT } & & \\
\hline & $\begin{array}{l}\text { Estación } \\
\text { Coahuila }\end{array}$ & $\begin{array}{l}\text { Los } \\
\text { Algodones }\end{array}$ & $\begin{array}{l}\text { San } \\
\text { Felipe }\end{array}$ & & \\
\hline Month & \multicolumn{3}{|c|}{ Fecal coliforms (MPN/100ml) } & DCL & ICL \\
\hline Jan & 3 & 3 & $<3$ & \multirow{12}{*}{240} & \multirow{12}{*}{1000} \\
\hline Feb & 3 & 3 & 3 & & \\
\hline Mar & 3 & 3 & 3 & & \\
\hline Apr & 3 & 3 & 6 & & \\
\hline May & 3 & 614 & 3 & & \\
\hline Jun & 26 & 562 & 3 & & \\
\hline Jul & 26 & 3 & 787 & & \\
\hline Aug & 42 & 3 & 131 & & \\
\hline Sep & 161 & 79 & 788 & & \\
\hline Oct & 146 & 18 & 1122 & & \\
\hline Nov & $2.4 \times 10^{7}$ & 3 & 3 & & \\
\hline Dec & $2.4 \times 10^{7}$ & 3 & 3 & & \\
\hline
\end{tabular}
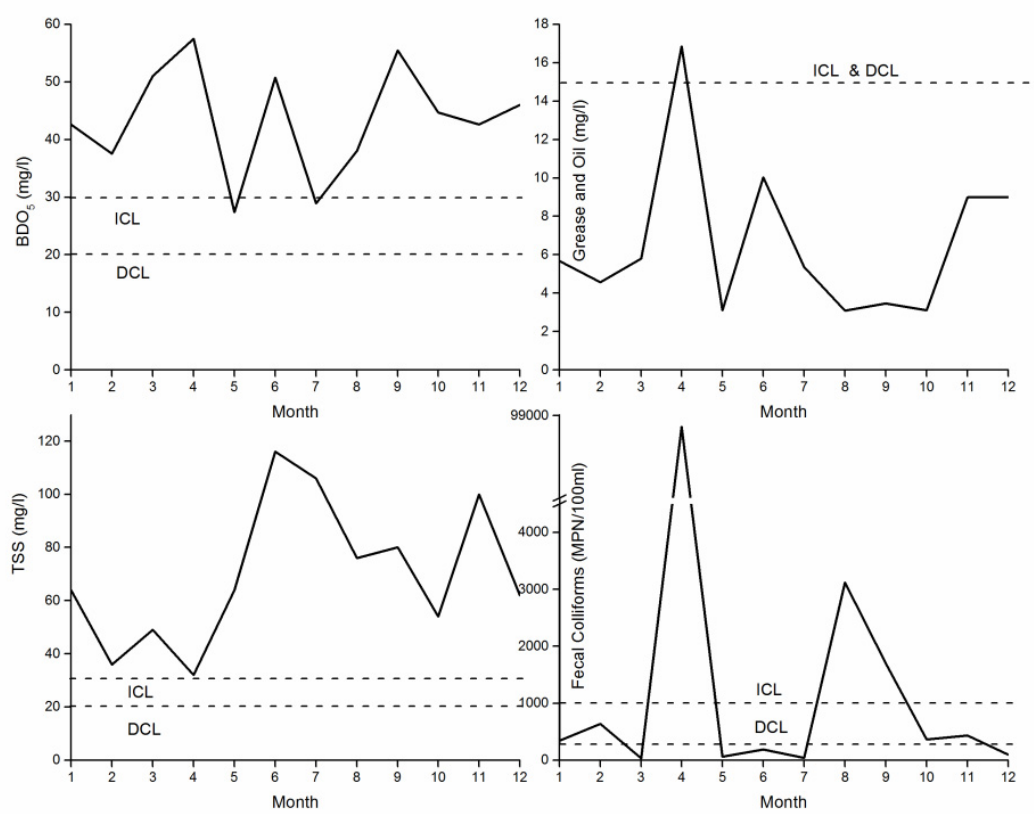

Figure 3: Results of parameter analyses for WTP Arenitas. 
throughout the year. The $15 \mathrm{mg} / \mathrm{l} \mathrm{limit}$ for grease and oil was met, with the exception of the month of April. The concentration of fecal coliforms was in the range of 340 to $86,740 \mathrm{MPN} / 100 \mathrm{ml}$ during the months of January, February, April, August, September and October, while the limit for direct contact was $240 \mathrm{MPN} / 100 \mathrm{ml}$ and 1000 for indirect contact.

\subsection{Proposals to improve the use of treated wastewater}

The bacteriological quality of water is considered the main reason for the establishment of guidelines and regulations for the safe use of treated waters in different applications. The World Health Organization considers that studies are necessary to ensure the effective and safe use of treated wastewater, as this increases the levels confidence found in the wider community (WHO [12]).

Some studies indicate that the determination and classification of effluent is of great importance for the adequate use and management of this resource, especially in the context of sustainable productivity and the rational use of natural resources (Ortiz [13]). The United States Environmental Protection Agency (EPA) considers that it is important the development of the preliminary environmental impact surveys on proposed irrigation systems using treated or untreated wastewater (EPA [14]). This study presents a plan of strategies to improve both the quality of effluent water, and the use of treated wastewater.

Table 5 shows the main aspects identified by this study which should be considered to ensure the best and most responsible use of wastewater treated by Mexicali's WTPs, which includes, among other things, measures to ensure crop quality, protect public health, and maintain the quality of the ecosystem.

\section{Conclusions}

In Mexicali, the reuse of water constitutes one of the most valuable tools we have to control pollution, recharge aquifers, and to face the challenge of increasing agricultural production. However, limited understanding of domestic wastewater within Mexicali, and incomplete water quality data make water reuse programs tentative and do not ensure agricultural sustainability and protection of public health. Although the effluent from the wastewater treatment plants does not comply consistently with the maximum permissible limits established in the Mexican Standard NOM-003-SEMARNAT-1997, the water is being used in the irrigation of crops and, as such, represents a risk to public health. The irrigation personnel and others who have either direct or indirect contact with water of poor quality could develop health problems, mainly as a result of bacteriological water pollution, while suspended solids can also affect the permeability of soils.

For many years, the lower section of the Colorado River has been a clear example of poor sustainable management practices and poor use of water, which have brought, as a consequence, an increase in the pollution of bodies of water and a decrease in the volumes of water destined for the maintenance of the 
Table 5: $\quad$ Proposals to improve the use of treated wastewater.

\begin{tabular}{|c|c|}
\hline Important item & Proposal \\
\hline $\begin{array}{l}\text { Quality of water treated } \\
\text { for ongoing compliance } \\
\text { with NOM-003- } \\
\text { SEMARNAT-1997 }\end{array}$ & $\begin{array}{l}\text { To make the necessary adjustments in each plant to } \\
\text { optimize treatment processes. } \\
\text { Periodic training for the operators of each plant. } \\
\text { To establish a program of periodic monitoring of the } \\
\text { quality of the effluent from the WTP. } \\
\text { The following additional proposal is made for WTP } \\
\text { Arenitas: } \\
\text { To make the requisite financial arrangements for the } \\
\text { construction of a second treatment stage, ensuring the } \\
\text { implementation of an activated sludge treatment system, } \\
\text { or a similar system that permits to improve the quality of } \\
\text { effluent for reuse that complies with NOM-003- } \\
\text { SEMARNAT-1997. }\end{array}$ \\
\hline $\begin{array}{l}\text { Infrastructure for } \\
\text { transport of treated water } \\
\text { for agricultural irrigation. }\end{array}$ & $\begin{array}{l}\text { To install purple lines for the conveyance of the effluent } \\
\text { to the agricultural and green areas to be irrigated. }\end{array}$ \\
\hline $\begin{array}{l}\text { Publicity and awareness } \\
\text { campaigns for users, } \\
\text { especially regarding the } \\
\text { technology involved. }\end{array}$ & $\begin{array}{l}\text { To establish a program of publicity and training regarding } \\
\text { the advantages of the use of treated wastewater, and to } \\
\text { change the paradigm dictating its use once the water } \\
\text { quality established in NOM-003-SEMARNAT-1997 is } \\
\text { reached as a constant. }\end{array}$ \\
\hline Public health. & $\begin{array}{l}\text { To provide users of wastewater, and the personnel } \\
\text { involved in irrigation, training in protection measures for } \\
\text { the safe handling of residual water. } \\
\text { To provide the necessary protective equipment to those } \\
\text { irrigation personnel who are in contact with treated } \\
\text { wastewater. }\end{array}$ \\
\hline Ecosystem preservation & $\begin{array}{l}\text { To devise measures to avoid harmfully affecting the } \\
\text { natural state of flora and fauna with bad effluent quality. }\end{array}$ \\
\hline Survey & $\begin{array}{l}\text { To increase the number of inspection visits to WTPs, } \\
\text { which are to include the revision of each process in order } \\
\text { to improve effluent quality. }\end{array}$ \\
\hline Certification of quality. & $\begin{array}{l}\text { To urge the National Water Commission to establish a } \\
\text { program for the periodic certification of the quality of } \\
\text { treated wastewater. }\end{array}$ \\
\hline
\end{tabular}

Colorado River Delta's wetlands. Treated wastewater is, therefore, a valuable resource for agriculture and the maintenance of the ecosystem in the region; however, it must be used responsibly.

Both the comprehensive management of wastewater and the participation and commitment of all stakeholders concerned, such as the institutions responsible for the administration and treatment of wastewater, community organizations and farmers, are vital if we are to manage our water resources efficiently and effectively. 


\section{Acknowledgements}

The authors acknowledge the support received from Universidad Autónoma de Baja California to carry out this study. This publication was possible thanks to the funds provided by the program PIFI-2013.

\section{References}

[1] Silva, Jorge; Patricia Torres y Carlos Madera, 2008. Reuso de aguas residuales domésticas en agricultura. Revista Agronomía 26-2 PROFE194.indd 347.

[2] INEGI. Instituto Nacional de Estadistica y Geografia e Informática. Censo de Poblacion y Vivienda, 2010.

[3] CONAGUA. Estadísticas. Situación del subsector de agua potable, alcantarillado y saneamiento. Mexicali: Comisión Nacional del Agua.

[4] CONAGUA. Programa Nacional Hidráulico. Mexicali: Comisión Nacional del Agua.

[5] Colima, M. Reporte Meteorológico. Mexicali: Comisión Nacional del Agua.

[6] Acosta, R. Economía del Agua en Baja California, Reuso de aguas residuales tratadas. Baja California: Universidad Autónoma de Baja California.

[7] Strauss, M. The practice of reuse of urban wastewater and human excreta in urban agriculture and aquacuture. RUAF Foundation filrd. www.ruaf.org/sites/default/files/ab wastewater.pdf

[8] Fernández, A (2010). Beber aguas residuales recicladas, es una alternativa a la escasez de agua que ya se utiliza en diversas poblaciones de todo el mundo, con garantías sanitarias, septiembre 2010. http://www.consumer.es/web/es/medio_ambiente/urbano/2010/09/01/1954 97.php

[9] Cepis (Centro Panamericano de Ingeniería Sanitaria y Ciencias del Ambiente). Inventario de la situación actual de las aguas residuales domésticas en Colombia. Sistemas integrados de tratamiento y uso de aguas residuales en América Latina: realidad y potencial. Perú. www.cepis.ops.oms.org

[10] Rivera R., Oscar L., Jesús C.H., Marco B. Contaminación por coliformes y helmintos en los ríos Texcoco, Chapingo y San Bernardino tributarios de la parte oriental de la cuenca del valle de México Revista internacional de contaminación ambiental, 23(2) 69-77, 2007.

[11] SEMARNAT Norma Oficial Mexicana, NOM-003-SEMARNAT-1997. Límites máximos permisibles de contaminantes para las aguas residuales tratadas que se reusen en servicio público.

[12] WHO A compendium of standards for wastewater reuse in the Eastern Mediterranean Region, World Health Organization Regional Office for the Eastern Mediterranean Regional Centre for Environmental Health Activities CEHA, Document WHO-EM/CEH/142/E. 
[13] Ortiz, J., García, L., Valdez, R., Lara, L., Rodríguez, H., and Osti, C. "Calidad agronómica de efluentes de plantas de tratamiento de aguas residuales. Tropical and Subtropical Agroecosystems, 10 (2009): pp. 355367.

[14] EPA Guidelines Wastewater irrigation management plan (WIMP) - a drafting guide for wastewater irrigators. June 2009. 